\title{
Analysis of Resistance Factors Implementation KKNI Oriented Curriculum with Six's Task at Electrical Engineering Department
}

\author{
Adi Sutopo $^{1}$, Dadang Mulyana ${ }^{1}$, Mustamam $^{1}$ \\ \{*adisutopo64@gmail.com,mulyana_dank2@yahoo.com,Mustamam65@gmail.com \} \\ Faculty of Engineering, Universitas Negeri Medan, Indonesia ${ }^{1}$
}

\begin{abstract}
KKNI Oriented curriculum implementation in teaching and learning activities in the Unimed developed with six's task student in the learning system. The success of the implementation of the six's tasks are not only from the resistance factors and support that can be derived from the students, lecturers and the availability of infrastructure facilities. The results of the study showed that the resistance factors faced by students is the availability of the ingredients and the appliance (58\%), The clarity of the task of the lecturers (48\%), feel less creative $(49.4 \%)$. Resistance Factors from a lecturer is time to assess the task students (53\%) and feel student motivation in performing tasks still low (76.4\%). six's task implementation can be done better when the institution provides better soft copy or and hard copy reference. Such is the case of lecturers give the task more clearly and the number of credits to be interdicted proportional so enough time to assess the student tasks.
\end{abstract}

Keywords: Six's task, resistance factors, support factors

\section{Introduction}

M Nasir (02-02,/2016) [1] said that in the era of MEA education we must produce resources that are able to compete because the competencies that can be made the standardized. The era of competition made them that have the competencies that will be so the winner. Based on this all universities must prepare their student to have competencies in accordance with the field of expertise.

One part of the implementation the curriculum is the tasks of the lecture who are assigned to the students. Lecturer, administrator and college must to suport implementation new curriculum. Altrichter, H (2005), state that a new curriculum may be described as an attempt to change teaching and learning practices which will also include the transformation of some of the beliefs and understandings hitherto existent in the setting to be changed [2].

The perfection of the task that made students not escape from supporting factor and resistance factors in completing tasks that can occur from the students, lecturers these sycophants then courses and the availability of the infrastructure of education.

The curriculum based on the Indonesian National collage Standard articles 11 and 12 as a set of plan and purpose settings, contents and teaching materials and how that is used as the implementation guidelines to achieve the goal of higher education [3]. Curriculum as a plan, manifested in a series of courses and student activities. Standard reference in determining the ability of graduate competency from Indonesian risearch and technology ministry is the 
framework of national qualification Indonesia (KKNI). KKNI arranged in the Regulation of the President of the Republic of Indonesia Number 8 Year 2012, consitution No 12 th 2012 and ministerial regulation no. 49 about SNPT 2014 [5][6][7].

KKNI aims to produce human resources from the teaching and learning process that is capable of producing the work and contribution of quality for the people of Indonesia. KKNI divided in nine (9) levels of qualification based on the mapping of a comprehensive employment conditions in Indonesia are reviewed from the income side (supply push) and users (demand pull) of labor [7] [8]. Scematically achievement of each level can be passed through formal education, non formal or work experience (UU 12 Th 2012 article 29)[5].

The implementation of the KKNI oriented curriculum in Unimed by six's task that are given on the students, which includes: routine tasks, critical book revieu, critical journal revieu, mini research, project task and engineering ideas. Based assessment 6 the task and added with a mid examination and final exams semester.

Six's task became the standard of teaching, learning activities and evaluation program in all departmen in the Unimed. Six's task ways to implementation KKNI curriculum and to reach university vision. Committee on a Conceptual Framework for New K-12 Science Education Standards (2012: 241) state that vision cannot be realized unless the standards permeate the education system and guide curriculum, instruction, teacher preparation and professional development, and student assessment [9].

So that students are expected to become more active and productive in the lecture for arrange scientific paper and pour the positive ideas the development of science and technology. So learning by experience which is based on a real life experience with the principles of learning to know, to do, to be and to live together.

\section{Methodology}

This research as a research policy evaluation with using survey methods. Sample research consist of 22 lecturer and 160 collage students. Data Collection by questionnaires and observation sheet instrument. Data analysis using descriptive statistics by SPSS $17^{\text {th }} \cdot[10]$.

\section{Result and Discussion}

The results of research on resistance factors faced by the students and lecturers in the implementation of the activities of the six (6) students' tasks as shown in table 1 and 2.

Table 1. Resistance Factors Faced by Students

\begin{tabular}{llcccc}
\hline No & \multicolumn{1}{c}{ Resistance Factors } & \multicolumn{3}{c}{ Prosentasi tendency } \\
\cline { 3 - 5 } & & just enough & enough & medium & Less \\
\hline 1 & the adequacy of the time & $40,7 \%$ & $14 \%$ & $32,7 \%$ & $12.7 \%$ \\
2 & availability of ingredients and the appliance & $20,7 \%$ & $21.3 \%$ & $41.3 \%$ & $16.7 \%$ \\
3 & clarity of tasks from Lecturers & $7.3 \%$ & $44.6 \%$ & $46,7 \%$ & $2 \%$ \\
4 & creativity of the students complete 6 Tasks & $12 \%$ & $28,7 \%$ & $46.0 \%$ & $12.7 \%$ \\
5 & achievement motivation & $18 \%$ & $33.3 \%$ & $39.4 \%$ & 9.3 \\
\hline
\end{tabular}


Table 2. Resistance Factors Faced By The Lecturers

\begin{tabular}{llcccc}
\hline No & \multicolumn{1}{c}{ Resistance Factors } & \multicolumn{3}{c}{ Prosentasi Tendency } \\
\cline { 3 - 6 } & & just enough & enough & medium & less \\
\hline 1 & The adequacy of the time & $40,7 \%$ & $14 \%$ & $32,7 \%$ & $12.7 \%$ \\
2 & Frequency in assessing the task & $11.8 \%$ & $35,3 \%$ & $35,3 \%$ & $17.7 \%$ \\
3 & The level of clarity in giving Task & $5.9 \%$ & $82,3 \%$ & 0 & $11.8 \%$ \\
4 & needs time to assess six's tasks & $23.5 \%$ & $23.5 \%$ & $41.2 \%$ & $11.8 \%$ \\
5 & Motivate students in completing tasks & 0 & $14 \%$ & $47 \%$ & $29.4 \%$ \\
\hline
\end{tabular}

Based on the results of the analysis of the data showed that the resistance factor that most of the students is the availability of the ingredients and the appliance $(58 \%$ stated medium and low). The availability of reference materials is important because the task that the student work based on reference from the book, journals print and on line, so that encourage students to think and act as a scientific basis in the academic climate scientific. supplying the source of this reference is important for good universities in the form of hand book, text books, scientific journals on line or hard copy.

The clarity of the task of the lecturers in providing the assignment as the theme or the main problem, clarity format, the collection of tasks can also be resistance factors, because $48 \%$ of students consider that the clarity of the task of the lecturers in the category of medium and low. The theme of the task and the format of the arrangement of tasks gives the direction of the student in completing the task so that when less clearly makes the difficult students in performing tasks. In addition, it can also undermine the student motivation in completing tasks become better and focused. It is important for lecturers to evaluate the tasks given how clearly level in the body/themes and format by asking the explanation from the students.

The availability of reference materials and laboratory facilities and the clarity of the 6 tasks can cause the creativity and student motivation in complete 6 tasks in the category of less $(49.4 \%)$ and can cause creativity also in the category of less $(48 \%)$. The same thing is also felt by the majority of lecturers $(76,4 \%)$ stating that student motivation in performing tasks still low.

Resistance factors for lecturers who are considered big enough is to provide an assessment of the six' task student (53\%). This can be caused by the lecturers got the burden of teaching more than 9 credits and the number of students each class more than 30 students, besides when if the collection of student tasks scheduled on the days at the end of the first semester so that the tasks of students become accumulated from several classes and courses. Thus, the lecturer needs more time to assess the work of students and the time available frightened still less $(53 \%)$.

The adequacy of the time preparing six's according to the lecturers and students in working on six's task is not the resistance factors because most states enough time to prepare planning lectures with six's tasks $(40,7 \%$ very good and $14 \%$ enough for lecturers and students). Based on this lesson plan for the first semester that will walk can be made earlier so that the readiness of the lecturers in the lesson plan can do better.

\section{Conclusion}

Based on the results of research can be summarized as follows:

a. Resistance Factors implementation of 6 tasks according to the students is the availability of the ingredients and the appliance (58\%), motivation achievement 
(58\%), the creativity of the students $(49.4 \%)$, The clarity of the task $(48 \%)$ and the adequacy of the time $(45 \%)$.

b. Resistance Factors for lecturers in the implementation of the 6 tasks student is motivating students $(73,6 \%)$, assess $(53 \%)$, the needs of the time assess $(53 \%)$.

c. Not many factors that inhibit for lecturers is the adequacy of the time in preparing for the six's task students

\section{References}

[1] M. Nasir, "Memasuki MEA, Kemenristekdikti akan Dorong Kompetensi mahasiswa," 15 mei 2017, 2016. .

[2] H. Altrichter, "Curriculum implementation - limiting and facilitating factors," 2005.

[3] S. Arifin, "Pengembangan Kurikulum Pendidikan Tinggi Sesuai KKNI," Work. Kurikulum Pendidik. Tinggi Direktorat Belmawa-Dikti, 2014.

[4] "Peraturan Presiden Republik Indonesia Nomor 8 Tahun 2012 Tentang Kerangka Kualifikasi Nasional Indonesia."

[5] "Permendikbud Nomor 49 tentang Standar Nasional Perguruan Tinggi."

[6] "Undang-Undang Nomor 12 Tahun 2012 Tentang Pendidikan Tinggi."

[7] Direktorat Pembelajaran Dan Kemahasiswaan, Panduan Penyusunan Capaian Pembelajaran Lulusan Program Studi. Direktorat Jenderal Pendidikan Tinggi Kementerian Pendidikan Dan Kebudayaan, 2014.

[8] Ristek Dikti, Kerangka Kualifikasi Nasional Indonesia Dokumen 001. Direktorat Jendral Pembelajaran dan Kemahasiswaan Kementerian Riset, Teknologi, dan Pendidikan Tinggi Republik Indonesia, 2015.

[9] Committee on a Conceptual Framework for New K-12 Science Education Standards, $A$ Framework For K-12 Science Education, Practices, Crosscutting Concepts, And Core Ideas. Washington: The National Academies Press, 2012.

[10] Wahana Komputer, Mengolah Data Statistik Hasil Penelitian dengan SPSS 17. Yogyakarta: Andi Offset, 2010 